Chas. Glaser,

Wm. Glenn,

A. J. Corning,

Charles E. Munroe,

Eugene Byrnes,

Wirt Tassin,

August E. Knorr,

Oma Carr,

T. C. Trescott,

Wm. H. Krug,

F. W. Clarke,

W. P. Cutter,
T. R. Wolf,

H. B. Hodges,

Edgar F. Smith,

Wm. M. Groevsnor, Jr.,

W. L. Dudley,

G. W. Lehmann,

J. B. Littlewood,

W. N. Mumper,

John Johns,

Edgar Richards,

Marcus Benjamin,

Lyman B. Hall.

\title{
THE WIDE-SPREAD OCCURRENCE OF BARIUM AND STRONTIUM IN SILICATE ROCKS.'
}

BY W. F. HILIEBRAND.

\begin{abstract}
$\triangle$ MONG the mass of published analyses of igneous eruptive $A$ and metamorphosed eruptive rocks, those in which barium
\end{abstract} and strontium are noticed are few indeed, unless the work has been of a special nature, like that of Sandberger in the development of the lateral secretion theory. Yet the very numerous analyses of igneous eruptive rocks of all ages and kinds made in the laboratory of the United States Geological Survey during the past thirteen years, have shown that these elements are distributed widely and in considerable quantity, in the United States at least, and doubtless elsewhere.

The percentages of barium and strontium oxides when present are usually below 0 .I per cent. each, but higher amounts are by no means uncommon, and for certain districts seem to be the rule rather than the exception. Within the past year two series of rocks from Colorado and Montana have been analyzed, both of which are noteworthy for the high percentages of barium found in them. Of seven rocks constituting the Colorado series six held from 0.13 to 0.18 per cent. $\mathrm{BaO}$, while in the seventh the percentage was 0.43 . The SrO ranged from 0.07 to 0.13 per cent. for six, and was 0.28 per cent. for that one highest in $\mathrm{BaO}$. Of thirteen geologically related rocks from Montana, embracing basic as well as acid and intermediate types, the range of $\mathrm{BaO}$

1 Read at the Baltinore meeting, December 27, I893. 
was from 0.19 to 0.37 , with an average holding of 0.30 per cent. Three others of the same series contained o. io per cent. or less. while the seventeenth carried 0.76 per cent. $\mathrm{BaO}$. The SrO ranged from 0.37 per cent. in the last instance to an average of 0.06 per cent. for the other sixteen.

In view of the above showing the question arises, why was not this general distribution sooner recognized? The answer is uncloubtedly given by the statement that it has not been the custom among chemists to look for barium and strontium in analyses of the kind under discussion, and doubtless for the following reasons :

Ist. A belief on the part of many that the two elements were absent from most rocks, this belief being based on the supposed rarity of the few rock-constituting minerals known to contain barium and strontium as noteworthy constituents.

2nd. Admitting the possibility of their presence in minute quantities, the unimportance as an aid to classification by the lithologist of the knowledge that a rock may contain a few hundredths of one per cent., more or less, of barium or strontium.

The unsoundness of the first argument has been sufficiently demonstrated by the data given above for rocks of the United States, which show likewise what serious errors may be incurred by neglect to test for the elements in question. Barium and strontium carrying minerals, sometimes with high percentages of one or both, are more common rock constituents than was formerly supposed.

With regard to the second point it may be said that if the present clecade or the next may be unable to make use of the knowledge referred to, this will probably not hold true of the lithologists of a still later period-an argument perhaps equally applicable to other elements than barium and strontium.

Regarding a further reason why barium has undoubtedly often been overlooked, the reader is referred to the following paper. 